\title{
Precarious conservation status of Pilgerodendron uviferum forests in their northern distribution in the Chilean Coastal Range
}

\author{
Estado de conservación precario de los bosques Pilgerodendron uviferum, en su límite \\ norte en la Cordillera de la Costa Chilena
}

\author{
Daniel P Soto ${ }^{a *}$, Carlos Le Quesne ${ }^{a}$, Antonio Lara ${ }^{a}$, , Martin F Gardner \\ *Corresponding author: aUniversidad Austral de Chile, Instituto de Silvicultura, casilla 567, Valdivia, Chile, \\ phone.: 56-063-221742, fax: 56-063-221230, danielsoto@uach.cl \\ bFORECOS Nucleus (Forest Ecosystemic Services to Aquatic Systems under Climatic Fluctuations), \\ Millennium Scientific Initiative Nucleus of the Ministry of Planning, Chile. \\ 'Royal Botanic Garden Edinburgh, 20A Inverleith Row, Edinburgh EH3 5LR, UK.
}

\begin{abstract}
SUMMARY
Pilgerodendron uviferum, ciprés de Las Guaitecas, is a long-lived member of the family Cupressaceae; it is dioecious, and endemic to the temperate forests of South America. Its geographic range extends over 1,600 km, from $39^{\circ} 35^{\prime} \mathrm{S}$ (Valdivia Province, Chile) to $54^{\circ} 20^{\prime} \mathrm{S}$ (Cape Horn), making it the conifer with the southernmost distribution in the world. North of $42^{\circ} \mathrm{S}$ latitude, the species is restricted to small, discrete forest stands in waterlogged soils. This paper describes four previously undocumented stands of $P$. uviferum in south-central Chile (39 $50^{\prime}$ ) -extending the known northern limit of the species in the Chilean Coastal Range (CCR)- and highlights its precarious conservation status. These small stands $(<2 \mathrm{ha})$ are isolated within a matrix of pastures and exotic forest plantations, and are subject to chronic disturbance by livestock grazing, logging, and burning. On the basis of dead burned snags and stumps, we estimated that recurrent burning and logging have resulted in a 57\% loss of P. uviferum stems, and an $80 \%$ loss of basal area in these stands. Current land use regimes in the study area are causing multiple threats to the viability of these stands. We recommend to develop a restoration program in order to preserve these geographical outlying $P$. uviferum populations.
\end{abstract}

Key words: forest remnants, swamp forests, threatened conifer, wetlands.

\section{RESUMEN}

Pilgerodendron uviferum, ciprés de Las Guaitecas, es una especie dioica, miembro de la familia de las Cupressaceae, endémica de los bosques templados de Sudamérica. Su distribución geográfica se extiende cerca de $1.600 \mathrm{~km}$, desde los $39^{\circ} 35^{\prime} \mathrm{S}$ (provincia de Valdivia) hasta los 5420' S (Cabo de Hornos), convirtiéndose en la conífera con distribución más austral de mundo. Al norte de los $42^{\circ} \mathrm{S}$ la especie se restringe a pequeños fragmentos de bosques ubicados en suelos inundados. El artículo describe cuatro rodales de P. uviferum no documentados en el centro-sur de Chile (39 $50^{\prime} \mathrm{S}$ ), extendiendo el límite norte de la especie en la Cordillera de la Costa de Chile (CCR), y resaltando su precario estado de conservación. Estos pequeños rodales $(<2$ ha) se encuentran aislados entre sí e inmersos en una matriz de praderas y plantaciones de especies exóticas, siendo permanentemente sujeto de alteraciones crónicas por ramoneo, cortas y fuego. Sobre la base de árboles muertos en pie y tocones, se estimó que las quemas recurrentes y cortas tienen como resultado una pérdida de $57 \%$ de los árboles y $80 \%$ del área basal en los rodales. Actualmente el régimen de uso del suelo del área de estudio es causa de múltiples amenazas para la viabilidad de estos rodales. Se recomienda implementar un programa de restauración a fin de preservar estas poblaciones geográficamente marginales.

Palabras clave: bosques remanentes, bosques húmedos, conífera amenazada, ñadis.

\section{INTRODUCTION}

The temperate rainforests of Chile and Argentina are considered to be among the 25 highest priority areas for the conservation of biodiversity in the world (Gil et al. 1999, Myers et al. 2000). This is due to their high level of endemism (ca. 50\%), and to the dramatic reduction of their original habitat area (ca. 70\%) that has occurred as a consequence of anthropogenic impacts (Smith-Ramírez 2004, Gardner et al. 2006), which is equivalent to the reduction in area experienced by these forests during the last glaciation (Armesto et al. 1994, 1998).

The three endemic and monotypic members of the Cupressaceae family found in this area have serious conservation problems (Veblen et al. 1976, Walter and Gillett 1998, Hilton-Taylor 2000). Among these spe- 
cies, ciprés de Las Guaitecas (Pilgerodendron uviferum [D. Don.] Florin) is the world's southernmost occurring conifer species, covering the greatest latitudinal distributional range $\left(39^{\circ} 35^{\prime}-54^{\circ} 20^{\prime} \mathrm{S}\right.$; ca. $\left.1,600 \mathrm{~km}\right)$, mainly in Chile, and existing as scattered populations in Argentina (Martínez 1981, Szeicz et al. 2000, Rovere et al. 2002). Pilgerodendron uviferum is a dioecious conifer that is a characteristic arboreal element of Chile's sub-Antarctic forests and Magellanic moorlands; it occupies humid sites with flat topographies in poorly drained areas with high water tables (Pisano 1977, Cruz and Lara, 1981, Moore 1983, Villagrán 1988, Allnutt et al. 2003). The wood of P. uviferum is highly resistant to decay (Woda 2003), so that fallen logs and snags may persist for decades or even centuries. It has well-defined tree rings and its radial growth is sensitive to climatic variations (Roig and Boninsegna 1991, Roig 1992, Boninsegna 1992). For these reasons, it has been utilised for palaeoclimate reconstruction (Roig 1991, Roig and Boninsegna 1991, Szeicz et al. 2000, 2003).

Pilgerodendron uviferum has been severely exploited, beginning in the $17^{\text {th }}$ century (Martínez and Muñoz 1988), due to the excellent quality of its wood (Diaz-Vaz 2002). Human-set fires have also severely reduced the area of these forests (Cruz and Lara 1981). Actually, most P. uviferum forests have standing burnt trees, or have been logged and have been dramatically affected by extensive livestock grazing, and as a result vast areas have failed to regenerate (Cruz and Lara 1981, Rovere et al. 2002, Allnut et al. 2003, Bannister 2004). Because of these threats, P. uviferum has been classified as vulnerable (Walter and Gillett 1998, Farjon and Page 1999, Hilton-Taylor 2000) by the IUCN (World Conservation Union), and has been included in Appendix 1 of the CITES convention, which regulates the international trade of threatened species. The relatively easy access afforded by the construction of new roads through pristine $P$. uviferum stands in the Aisén Region $\left(48^{\circ} 35^{\prime}-50^{\circ} 20^{\prime} \mathrm{S}\right)$ has facilitated further logging activities in the last few years.

North of $42^{\circ} \mathrm{S}$ in Chile, the species is restricted to small, isolated populations (Donoso 1993, see figure 1). These populations, considered to be remnants from Pleistocene glacial refugia (Villagrán 1991, Villagrán and Armesto 2005), are genetically different from the southern more contiguous populations (Premoli et al. 2002, Allnutt et al. 2003). Corral Bay $\left(40^{\circ} \mathrm{S}\right)$ has been documented as the northern distributional limit of $P$. uviferum in the Chilean Coastal Range (CCR) (CONAF 2000). However, there has been no previous documentation of the presence of this species north of this locality. Within this context, the main objectives of this study are: (i) to locate $P$. uviferum populations north of its documented distributional range in the CCR, (ii) to describe P. uviferum stand structure, composition, regeneration, radial growth and sexual ratio, and (iii) to evaluate the anthropogenic threats to their persistence.

\section{METHODS}

Study area. The study area extends between $39^{\circ}$ and $40^{\circ} \mathrm{S}$ in the CCR, and it covers approximately $4,500 \mathrm{~km}^{2}$. The forest landscape here is dominated by exotic plantations of Pinus radiata D. Don and Eucalyptus spp. (figure 1).

This area has a temperate climate with a Mediterranean influence. The study sites occupied by $P$. uviferum receive between $2,500 \mathrm{~mm}$ (low elevation 0 to $300 \mathrm{~m}$ a.l.s.) and $6,000 \mathrm{~mm}$ (high elevation 300 to $1000 \mathrm{~m}$ a.l.s.) of annual precipitation, concentrated in winter months (June-August). The mean annual temperature varies between 10 and $12^{\circ} \mathrm{C}$ (Di Castri and Hajek 1976, Woda 2003). P. uviferum grows in poorly-drained soils that are constantly saturated with water. In the northern portion of the CCR $\left(40^{\circ} 10^{\prime} \mathrm{S}\right)$ Lara et al. (1999a) documented the presence of P. uviferum in the least productive sites presenting very acidic organic soils (pH from 3.5 to 4.7), classified as Gleysols and Histosols (FAO-UNESCO 1971, Cruz and Lara 1981).

Data collection and analysis. To locate the stands, the potential sites were delineated; these sites were characterized by nearly flat areas in portions of watersheds presenting little outflow; conditions that can be found in headwaters and waterlogged lowlands within the study area. Based on local knowledge and on 1:20,000 scale aerial photographs, the presence of $P$. uviferum small forest stands was possible to be located in the field. The exact position for each stand located stand was recorded using a GPS, and its area was estimated.

Three 20x20 m plots were set up at each study stand where the diameter at breast height (DBH), total height (TH), and diameter at stump height at $30 \mathrm{~cm}$ above ground (DSH) were measure for all P. uviferum individuals $>5 \mathrm{~cm}$. The basal area (the total cross-sectional area at breast height of all the trunks, expressed in $\mathrm{m}^{2} \mathrm{ha}^{-1}$ ) of all individuals in each stand previous to logging was estimated. Linear regression analysis was carried out, using the DSH and DBH variables, to reconstruct the residual structures of the P. uviferum-stands. To assess the quality of the regression $r^{2}$ (coefficient of determination), MSE (mean square error) and $P$ (probability of the $\mathrm{F}$ value) were used.

In the interior of each plot, six $2 \times 2 \mathrm{~m}$ subplots $\left(24 \mathrm{~m}^{2}\right.$ in each plot and $72 \mathrm{~m}^{2}$ in each stand) were installed, where seedlings $<2 \mathrm{~m}$ in TH, and saplings $\geq 2 \mathrm{~m}$ in TH and $<5$ $\mathrm{cm}$ DBH of every tree species were counted, following the methodology of Fraver et al. (1999). Paired-sample $t$ tests were also carried out to compare the seedling and sapling density of $P$. uviferum with that of other species on sites.

Given the dioecious character of $P$. uviferum, the individual trees bearing visible reproductive structures (male and female cones), during spring-summer, were counted in each plot. Differences between male and female ratios (M:F)were determined with $\chi^{2}$ analysis based observed vs. expected (1:1) frequencies (Núñez et al. in press). Two increment cores were extracted from each of three domi- 


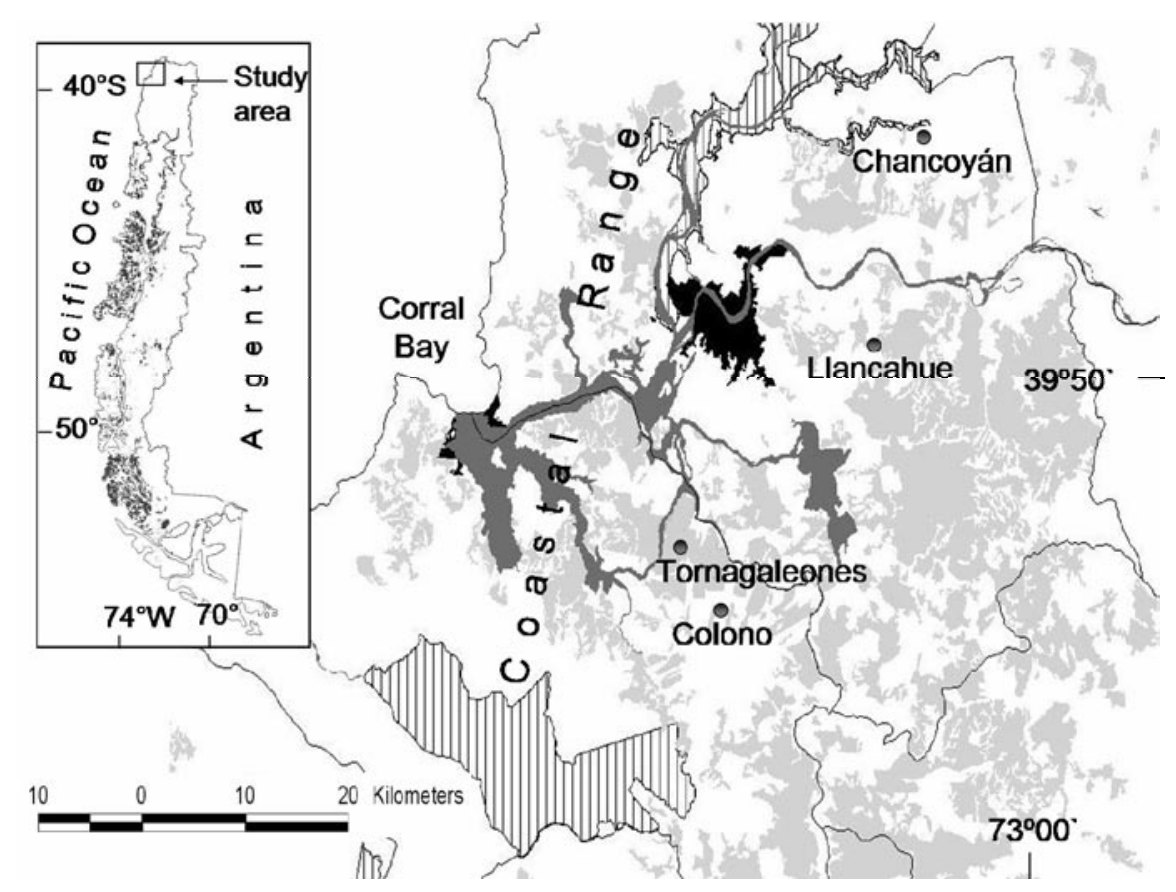

Figure 1. Location of the four P. uviferum stands studied in the Coastal Range Cordillera indicated by gray dots (Chancoyán, Llancahue, Tornagaleones and Colono). Exotic plantations of Eucalyptus spp. and Pinus radiata are indicated with light grey, rivers in dark grey, the city of Valdivia in black, and government protected areas are represented by a polygon with straight line surface. In the small-left map the shaded area shows the distributional range in Chile of $P$. uviferum.

Localización de los cuatro rodales de P. uviferum estudiados en la Cordillera de la Costa (puntos grises), las plantaciones (Eucalyptus spp. y Pinus radiata) en gris claro, ríos en gris oscuro, ciudad de Valdivia en negro y áreas protegidas por el gobierno chileno con achurado. En el mapa de la izquierda, el área sombreada muestra la distribución natural de los bosques de P. uviferum.

nant trees per plot (from nine individuals in each stand), to determine the age and mean annual diameter increment (MAI) for each stand. To verify the statistical differences in diameter structure, height, and MAI, an ANOVA and the Tukey HSD paired means test (Steel and Torrey 1988) were carried out.

The land-uses of the surrounding matrices in which the stands were located (e.g. pastureland, forest plantation, old growth native forest, second growth native forest) were described. To quantify the disturbances that have affected each stand, we followed the criteria proposed by Rovere et al. (2002), which consider human-set fires, logging, livestock grazing, and drainage works. Qualitative values were assigned to these alterations, ranging from 0 (no apparent alteration) to 1,2 , and 3 (alterations of lesser to greater intensity).

\section{RESULTS}

The study sites are isolated distinctive forest stands, with areas $<2$ ha, located at elevations between 5 and $315 \mathrm{~m}$ a.s.l. (figure 1 , table 1 ).
Table 1. General characteristics of the studied forests stands. Características generales de los rodales estudiados.

\begin{tabular}{lcrrrc}
\hline \multicolumn{1}{c}{ Stand } & Aspect & $\begin{array}{c}\text { Slope } \\
\%\end{array}$ & $\begin{array}{c}\text { Elevation } \\
\text { m a.s.l. }\end{array}$ & $\begin{array}{c}\text { Area } \\
\text { (ha) }\end{array}$ & Ownership \\
\hline Chancoyán & None & 0 & 5 & 0.76 & Private landowner \\
Colono & NE & 6 & 205 & 1.91 & Private landowner \\
Llancahue & SE & 8 & 300 & 1.82 & Public Land \\
Tornagaleones & NE & 12 & 315 & 1.54 & Timber Company \\
\hline
\end{tabular}

The stands show evidence of extensive anthropogenic disturbance. The Colono and Tornagaleones stands are the most disturbed due to high levels of logging and livestock grazing, impacts to the water table, and past fires. Concerning land uses, Chancoyán (table 2) is surrounded by a matrix of evergreen broadleaf forest growing on a soil with a high water table, locally known as "hualve". At present, the landowners are building ditches to drain the soil and replacing this native forest matrix for agricultural land uses (subsistence farming and livestock grazing). Seventy five percent of the perimeter of the Colono stand is occupied 
by Pinus radiata plantations that extend to the very edge of the stand. The remaining $25 \%$ of the stand's perimeter is subjected to chronic livestock grazing. Seventy percent of the Llancahue stand's perimeter is occupied by secondgrowth native forest that regenerated after human-set fires burned the area ca. 50 to 70 years ago. The remaining $30 \%$ of the stand's margin limits with an old pasture, which is being colonized by native shrubs, due to overgrazing by livestock, is being converted into a dense thicket. Finally, the Tornagaleones stand is completely surrounded by Eucalyptus nitens plantations (table 2).

Table 2. Degree of disturbance in the different stands, where: $0=$ no apparent disturbance, and 1, 2, and $3=$ disturbance from lesser to greater intensity (see Soto 2004).

Grado de alteraciones en los diferentes rodales, donde: $0=$ alteración no aparente, y 1,2 y $3=$ alteraciones de menor a mayor intensidad.

\begin{tabular}{lcccc}
\hline Stand & $\begin{array}{c}\text { Fire } \\
\text { evidence }\end{array}$ & $\begin{array}{c}\text { Livestock } \\
\text { grazing }\end{array}$ & Logging & $\begin{array}{c}\text { Water table } \\
\text { impacts }\end{array}$ \\
\hline Chancoyán & 0 & 3 & 0 & $3 *$ \\
Colono & 2 & 3 & 3 & $2 \#$ \\
Llancahue & 2 & 3 & 2 & 1 \\
Tornagaleones & 3 & 3 & 3 & $3 \#$ \\
\hline
\end{tabular}

* Anthropogenic drainage works. \# Perimeter with forest plantation with high evapotranspiration rates.

The Chancoyán and Llancahue sites exhibit multispecific multilayered forest stand structures, while Colono and Tornagaleones sites exhibit simple stand structures dominated by P. uviferum (table 3).
Chancoyán has the greatest mean diameter (11.2 \pm Standard Deviations (SD) $5.2 \mathrm{~cm})$ and height $(8.6 \pm 2.3 \mathrm{~m})$. In Llancahue, $P$. uviferum shares the dominance of the canopy with Nothofagus nitida (table 3). The stands do not exhibit statistically significant differences in mean diameters (ANOVA, $\mathrm{F}_{4.07}=0.337, P=0.7988$ ) or in mean heights $\left(\mathrm{F}_{4.07}=2.8811, P=0.1077\right)$ of $P$. uviferum and other tree species (table 3 ).

Three stands (Colono, Llancahue, and Tornagaleones) have dead P. uviferum trees that were killed by fires and logging activities (table 2). Reconstruction of the tree diameters provided a highly efficient fit and validation $(P<0.0001$; figure 2$)$. The reconstructed mean diameter was $18.8 \pm 10.5 \mathrm{~cm}$, and the present mean DBH $7.4 \pm 3.4$ $\mathrm{cm}$, which yields highly significant differences $(\mathrm{t}=7.4$, $\mathrm{df}=48, P<0.0001)$. However, in the Tornagaleones stand the present diameter $(9.8 \pm 8.6 \mathrm{~cm})$ is greater than the diameters for cut and dead trees $(8.6 \pm 3.3 \mathrm{~cm})$, which does not yield significant differences $(\mathrm{t}=0.41, \mathrm{df}=10$, $P=0.687$; table 3 ).

Differences in mean diameter increment (MAI) of P. uviferum were highly significant among sites $\left(\mathrm{F}_{3.49}=33.44\right.$, $P<0.0001)$. However, Chancoyán and Colono did not have statistically significant differences in mean growth (Tukey HSD test; $P=0.203$, table 3 ).

The regeneration of $P$. uviferum was significantly different from that of other tree species as a group for Colono, and not different for Tornagaleones (table 4). On the other hand, in Chancoyán and Llancahue the regeneration of other tree species was significantly different from that of P. uviferum (table 4). Pilgerodendron uviferum dominated the total number of seedlings and saplings in Colono and Tornagaleones, representing $66.8 \%$ and $71.8 \%$, respec-

Table 3. Summary of the stand structure attributes.

Resumen de los atributos estructurales de los rodales.

\begin{tabular}{|c|c|c|c|c|c|c|c|}
\hline Stand & Species & $\mathrm{N}^{\mathrm{o}}$ trees $\mathrm{ha}^{-1}$ & $\begin{array}{l}\text { Basal Area } \\
\mathrm{m}^{2} \mathrm{ha}^{-1}\end{array}$ & $\begin{array}{c}\text { Mean } \mathrm{DBH}(\mathrm{cm}) \\
\pm \mathrm{SD}\end{array}$ & $\begin{array}{l}\text { Age } \\
(\mathrm{yr})\end{array}$ & $\begin{array}{c}\text { MAI* } \\
(\mathrm{cm} / \mathrm{yrs})\end{array}$ & $\begin{array}{c}\text { Mean\# TH }(\mathrm{m}) \\
\quad \pm \text { SD }\end{array}$ \\
\hline \multirow[t]{5}{*}{ Chancoyán } & P. uviferum & 700 & 6.6 & $11.2 \pm 5.2$ & 71 & $0.299 \mathrm{a}+$ & $8.6 \pm 2.3$ \\
\hline & Gevuina avellana & 125 & 1.1 & $9.7 \pm 2.5$ & - & - & $6.3 \pm 2.7$ \\
\hline & Drimys winteri & 125 & 0.5 & $6.7 \pm 1.9$ & - & - & $4.2 \pm 0.6$ \\
\hline & Tepualia stipularis & 475 & 3.0 & $8.1 \pm 2.4$ & - & - & $6.7 \pm 1.2$ \\
\hline & Weinmania trichosperma & 75 & 4.5 & $8.1 \pm 13.3$ & - & - & $6.7 \pm 1.7$ \\
\hline Colono & P. uviferum & $175(96)$ & $1.5(6.1)$ & $8.9 \pm 4.2$ & 70 & $0.272 \mathrm{a}$ & $4.5 \pm 0.9$ \\
\hline \multirow[t]{3}{*}{ Llancahue } & P. uviferum & $1,325(325)$ & $4.7(6.7)$ & $8.3 \pm 4.7$ & 298 & $0.079 \mathrm{c}$ & $3.9 \pm 3.9$ \\
\hline & Nothofagus nitida & 200 & 3.2 & $8.4 \pm 4.8$ & - & - & $6.1 \pm 3.8$ \\
\hline & Tepualia stipularis & 825 & 3.4 & $7.9 \pm 4.4$ & - & - & $2.8 \pm 2.5$ \\
\hline Tornagaleones & P. uviferum & $420(160)$ & $3.1(2.3)$ & $8.2 \pm 4.5$ & 48 & $0.200 \mathrm{~b}$ & $3.9 \pm 0.8$ \\
\hline
\end{tabular}

* Mean annual diameter increment, at breast height. \# Total Height. + Different letters for growth indicate statistically significant differences (Tukey HSD test, $P<0.05), \mathrm{n}=18$ samples per stand. Numbers between parentheses indicate values of density and basal areas of dead individuals. The sums of the values between parentheses and the preceding values in each cell indicate the values previous to anthropogenic disturbances. 
tively. The number of seedlings and saplings of the other tree species in the least disturbed stands, Chancoyán and Llancahue, was 72.3 and $71.8 \%$, respectively, the remainder being $P$. uviferum (table 4).

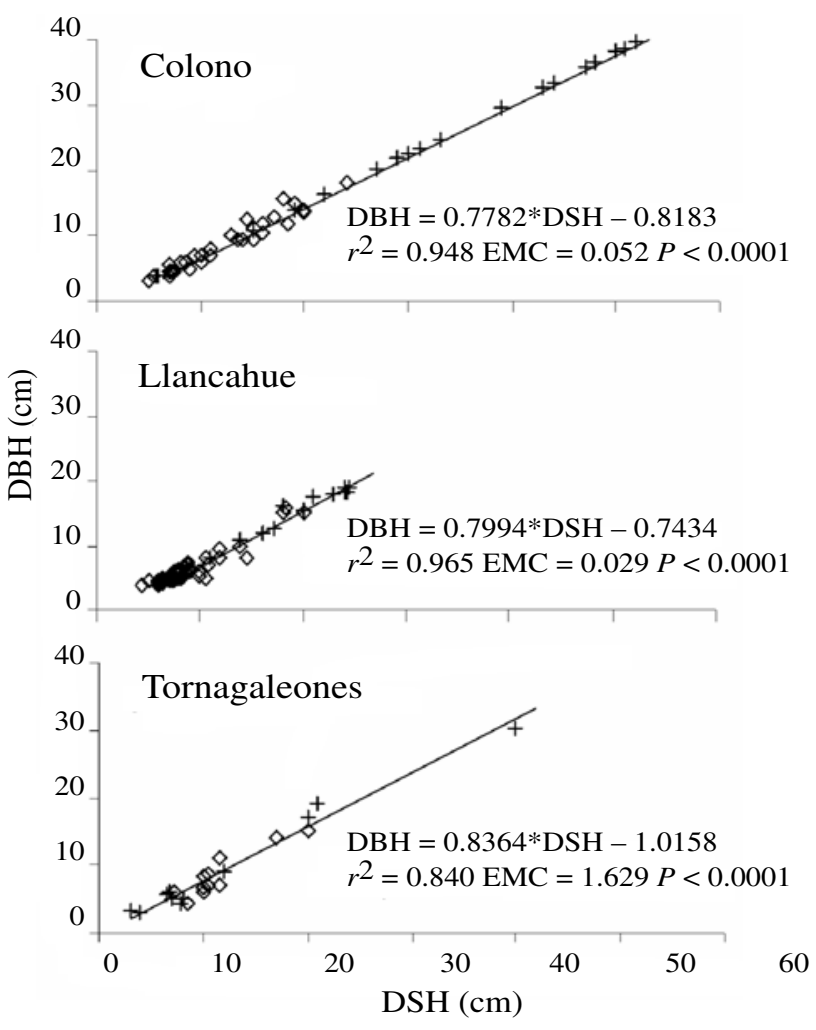

Figure 2. Relationships between diameter at stump height (DSH) and diameter at breast height (DBH), and equations for the reconstructions of lost structure of $P$. uviferum stands in CCR. Diamond shows living trees, and crosses show dead and cut trees.

Relación entre DSH (diámetro a la altura del tocón) y DBH (diámetro a la altura del pecho), y ecuación para la reconstrucción de la estructura perdida de los rodales de P. uviferum en la Cordillera de la Costa. Diamantes muestran árboles vivos, y cruces muestran árboles muertos y cortados.

Table 4. Regeneration (seedlings + saplings) of $P$. uviferum and other tree species. especies arbóreas.

Regeneración (plántulas y brinzales) de P. uviferum y otras

\begin{tabular}{lrrr}
\hline Stands & P. uviferum & Others species & $t$-value \\
\hline Chancoyán & $972 \pm 635$ & $9,442 \pm 1,048$ & $-15.24^{* *}$ \\
Colono & $4,860 \pm 1,577$ & $971 \pm 240$ & $5.03^{*}$ \\
Llancahue & $694 \pm 240$ & $2,221 \pm 240$ & $-5.50^{*}$ \\
Tornagaleones & $1,805 \pm 240$ & $694 \pm 240$ & $3.99 \mathrm{~ns}$ \\
\hline
\end{tabular}

All stands with 2 degree of freedom, ns: not significant $* P<0.05$, ** $P<0.01$.
The presence of male cones in $P$. uviferum trees was greater (21.0 \pm SD 13.5) than that of female cones (10.0 \pm SD 4.1) in every stand. In percentage, the presence of male individuals varied between 61 and $72 \%$ of all of the trees with recognizable reproductive structures in each stand (Table 5). The presence of males is highly different in relation to female for all study stands $(P=0.009)$. The most disturbed stands, Colono and Tornagaleones have differences between male vs. female ratios $(P<0.05)$, but these ratios increased in 2.3 for Chancoyán and 2.6 for Llancahue $(P<0.001)$, those being the less disturbed stands (table 5).

Table 5. Flowering P. uviferum individuals and sex ratio M: F (Male:Female) in the study stands.

Individuos florecidos de $P$. uviferum y razón sexual en los rodales de estudio.

\begin{tabular}{lccccl}
\hline Sites & $\begin{array}{c}\text { Sampled } \\
\text { trees* }\end{array}$ & Flowering & Male & Female & M:F \\
\hline Chancoyán & 84 & $33(39.3 \%)$ & $23(69.7 \%)$ & $10(30.3 \%)$ & $2.3^{* *}$ \\
Colono & 21 & $13(61.9 \%)$ & $8(61.5 \%)$ & $5(38.5 \%)$ & $1.6^{*}$ \\
Llancahue & 160 & $54(33.7 \%)$ & $39(72.2 \%)$ & $15(27.8 \%)$ & $2.6^{* *}$ \\
Tornagaleones & 50 & $24(48 \%)$ & $14(58.3 \%)$ & $10(41.7 \%)$ & $1.4^{*}$ \\
Mean \pm SD & $78.7 \pm 59.9$ & $31.0 \pm 17.4$ & $21.0 \pm 13.5$ & $10.0 \pm 4.1$ & $2.1^{* *}$ \\
\hline
\end{tabular}

* all individuals identified in the stands (three plots per stand). ns: not significant $* P<0.05$, ** $P<0.01$.

\section{DISCUSSION}

The four studied forest stands are the northernmost known P. uviferum populations in the Coastal Range of south-central Chile ( $\left.39^{\circ} 45^{\prime}-39^{\circ} 57^{\prime} \mathrm{S}\right)$. In Llancahue (39 49' S), P. uviferum is associated with Nothofagus nitida (Phil.) Krasser., whose northern distribution limit was formerly thought to be located within the Valdivia National Reserve $40^{\circ} \mathrm{S}$ (CONAF 2000). Therefore, Llancahue would be the new northernmost documented occurrence of $N$. nitida in the CCR, $80 \mathrm{~km}$ from its previously reported northern distribution limit. $N$. nitida is an evergreen species, restricted to southern Chilean forests with oceanic climatic influences, that often occurs on waterlogged soils at low elevations, where it can coexist with $P$. uviferum, as it does in Llancahue.

The study stands are found within highly disturbed matrices (table 2), which range from fast-growing exotic forest plantations to agriculture and pasturelands. In three of the stands (Colono, Llancahue and Tornagaleones) evidence of past human-set fires was found, affecting stand structure and species composition (tables 2 and 3). Pilgerodendron uviferum trees of all sizes have been cut for timber at these sites. Trees from the larger diameter classes in Colono and Llancahue were used for lumber, and trees from the smaller diameter classes in Tornagaleones 
were used as fence poles (figure 2). The stand structures have been severely modified, as indicated by the reduction in the number of trees per ha and the basal area by up to $57 \%$, and up to $80 \%$, respectively (table 3 ).

Colono and Tornagaleones stands, despite having been severely degraded (table 2), have higher percentages of $P$. uviferum seedlings and saplings over the total, compared to the other stands (table 4). The successful regeneration of $P$. uviferum in these disturbed sites with open canopies is explained by the relatively shade-intolerant character of the species (Donoso 1993, Lara et al. 2006). This would indicate that these stands are undergoing a slow process of recovery following the described anthropogenic disturbances. It has been claimed that $P$. uviferum recovery in disturbed areas is only possible if the soils remain waterlogged (Plaza 2001, Szeicz et al. 2003). Therefore, matrices of fast-growing Pinus radiata plantations, which have high evapotranspiration rates (Vertessy 1999, Oyarzún and Huber 1999, Oyarzún et al. 2005), could retard or hamper $P$. uviferum regeneration in the stands surrounded by such plantations. Drainage ditches constructed within matrices dedicated to agriculture and pastures may also have a negative impact on $P$. uviferum regeneration (tables 2 and 4). These effects would lead to the decrease of the dominance of this species in these marginal, highly fragmented stands, and its eventual replacement by other species. Nevertheless, long-term research is needed to properly assess these trends.

Only between 34 and $62 \%$ of mature P. uviferum trees bear reproductive structures at each stand. Between 27 and $42 \%$ of these reproductive individuals bear female cones (table 5). The scarcity of reproductive structures could be due to the stressful conditions being experienced by these individuals at the northern limit of the species geographic range as is the case for another Cupressaceae Austrocedrus chilensis (D. Don.) Pic. Serm. et Biz. in its northern limit in Argentina (Rapoport and Drausal 1979). In all stands the sex-ratio was balanced towards male individuals (table 5). However, in the most disturbed stands such as Colono and Tornagaleones, the sex-ratio tends to be $1: 1$, but in those presenting a low percentage of flowering trees, it is higher (13 and 24\%, respectively). In the case of the less disturbed stands as Chacoyán and Llancahue, the number of flowering trees is higher (33 and 54\%, respectively) showing an unbalanced sex-ratio with higher proportion of male trees. On the other hand, a recent study of biogeographical gradient of sexes in A. chilensis shows that female trees are found in moistured and shaded slopes (east and south) sites. However, male trees prefer xeric and high-radiation slopes (west and north) sites (Núñez et al. in press). Our study shows that stands with higher levels of $P$. uviferum regeneration also had a greater share of female individuals, and vice versa; a possible indication of the importance of female individuals to assure seed production and seedling recruitment (table 4 and 5). Nevertheless, $P$. uviferum recruitment by layering and root suckering has been reported in Chiloé Island (Cruz and Lara 1981, Lara et al. 2006).

Among the southern South American Cupressaceae species, $P$. uviferum has the highest genetic variability among populations specially in its northern limit, where our study stands are located (Allnutt et al. 2003, Premoli et al. 2001, 2002). Moreover, P. uviferum is considered to be an excellent high resolution proxy for the reconstruction of past climates, due to its extensive distribution, its longevity (850 years), and to the marginality of the environments in which it grows (Roig 1991, Szeicz et al. 2000, 2003). These characteristics, in addition to the anaerobic reducing conditions in the soil and subsoil, which are conducive to the preservation of plant macrofossil and pollen records, lead us to emphasize the importance of the conservation of these unique stands, which have been considered as refugia for the flora from the last Pleistocene glaciation (Villagrán 1991, Premoli et al. 2002, Allnutt et al. 2003).

These stands are located in an area that due to its biodiversity and endemism is of high priority for conservation on a local, regional and global scale (Armesto et al. 1998, Myers et al. 2000, Lara et al. 2003, Smith-Ramírez 2004, Conservation International 2005). Therefore, it is urgent to work toward the protection and restoration of these stands. Conversion of native forests to agriculture, pasture lands, and forest plantations in the valdivian rainforest Ecoregion (Lara et al. 1999b) increase the threats to these small, marginal forest stands (figure 1). The creation of new protected areas, as well as the development of conservation and restoration programs directed towards these northernmost stands should be given a high priority.

Future research should address the location of new stands and studies on the genetic variability of the stands and compare these with other genetic studies that have been carried out on P. uviferum. As a result of our studies, it is clear that urgent action should be taken on the protection and restoration of $P$. uviferum stands located in its northernmost distribution in the CCR. Such plans should involve the different stakeholders, such as the Chilean Forest Service (CONAF), landowners, forest companies, research institutions and non governmental organizations. Fencing, establishment of buffer areas around the stands, plantations with seedlings from local seed sources, and effective protection against fire, are among the activities that should have priority within any conservation strategy.

\section{ACKNOWLEDGEMENTS}

We would like to thank the following people for their valuable comments: R Brant (Q.E.P.D.), CP Soto, GT Soto, A Martínez, C Lusk, C Echeverría, and JE Schlatter. Laboratory and field assistance was also given by J Bannister, R Bertín, D Stark, R Rivera, D Uteau, D Christie, and C Zamorano. D Ekblaw for his help with the English. The authors are grateful for the support provided by BIOCORES (contract 
$\mathrm{N}^{\mathrm{o}}$ ICA-CT-2001-10095 by the European Commission) and the Scientific Millennium Initiative, from the Ministry of Planning (FORECOS P04-065-F).

\section{REFERENCES}

Armesto JJ, C Villagrán, C Donoso. 1994. Desde la era glacial a la industrial: la historia del bosque templado chileno. Ambiente y Desarrollo 10: 66-72.

Armesto JJ, R Rozzi, C Smith-Ramírez, MK Arroyo. 1998. Conservation targets in South American temperate forests. Science 282: 1271-1272.

Allnutt TR, AC Newton, AC Premoli, A Lara. 2003. Genetic variation in the threatened South American conifer Pilgerodendron uviferum (Cupressaceae), detected using RAPD markers. Biological Conservation 100(1): 9-18.

Boninsegna JA. 1992. South American dendrochronological records. In Bradley, RS and PD Jones ed. Climate Since A.D. 1500. New York, USA. Chapman and Hall. p. 446-462.

Bannister JR. 2004. Estado de conservación de Ciprés de las Guaitecas en el área norte de la Cordillera de Pirulil, Isla Grande de Chiloé. Tesis de Ingeniero Forestal. Valdivia, Chile. Facultad de Ciencias Forestales, Universidad Austral de Chile. 49 p.

CONAF (Corporación Nacional Forestal, CL). 2000. Plan de Ordenación de la Reserva Forestal Valdivia. Valdivia, Chile. CONAF-GTZ. 201 p. (Documento interno).

Cruz G, A Lara. 1981. Tipificación, cambio de estructura y normas de manejo para Ciprés de las Guaitecas (Pilgerodendron uviferum [D. Don] Florin) en la Isla Grande de Chiloé. Tesis Ingeniero Forestal. Santiago, Chile. Facultad de Ciencias Forestales, Universidad de Chile. 215 p.

Di Castri F, ER Hajek. 1976. Bioclimatología de Chile. Santiago, Chile. Pontificia Universidad Católica de Chile. 129 p.

Díaz-Vaz JE, H Poblete, R Juacida, F Devlieger. 2002. Maderas comerciales de Chile. Valdivia, Chile. Marisa Cúneo Ediciones. 126 p.

Donoso C. 1993. Bosques Templados de Chile y Argentina: Variación, estructura y dinámica. Santiago, Chile. Universitaria. $484 \mathrm{p}$.

Farjon A, CN Page. 1999. Conifers. Status Survey and Conservation Action Plan. IUCN/SSC Conifer Specialist Group. Gland, Switzerland and Cambridge, UK. IUCN. $121 \mathrm{p}$.

FAO-UNESCO, 1971. Soil map of the world. South America, IV. Paris.

Fraver S, ME González, F Silla, A Lara, MF Gardner. 1999. Composition and structure of remnant Fiztroya cupressoides forests of southern Chile's central depression. Journal of the Torrey Botanical Society 126: 49-57.

Gil PR, CG Mittermeir, RA Mittermeir. 1999. Hotspots: Earth's Biologically wealthiest and most threatened ecosystem. CEMEX, Mexico city, Mexico. 430 p.

Gardner MF, P Hechenleitner, PI Thomas, C Echeverría, B Escobar, P Brownless, C Martínez. 2006. Threatened Plants of Central and South Chile. Distribution, Conservation and Propagation. Valdivia, Chile. Universidad Austral de ChileRoyal Botanic Garden Edinburgh. 188 p.

Hilton-Taylor C. 2000. 2000 IUCN Red List of Threatened Species. Gland, Switzerland and Cambridge, UK. IUCN. 911 p.
Lara A, S Fraver, JC Aravena, A Wolodarsky-Franke. 1999a. Fire and the dynamics of Fitzroya cupressoides (alerce) forests of Chile's Cordillera Pelada. Ecoscience 6(1): 100-109.

Lara A, ME Solari, P Rutherford, O Thiers, R Trecaman. 1999b. Cobertura de la vegetación original de la ecoregión de los bosques valdivianos en Chile hacia 1550. Valdivia, Chile. Proyecto FB49 WWF-UACH. 32 p. (Informe Técnico).

Lara A, D Soto, JJ Armesto, PJ Donoso, C Wernli, L Nahuelhual, F Squeo. 2003. Key scientific components for a national policy regarding the uses, services and conservation of native forests in Chile. Reunión Científica sobre Bosques Nativos. Valdivia, Chile. Universidad Austral de Chile, Iniciativa Científica Milenio de Mideplan. 134 p.

Lara A, C Donoso, B Escobar, A Rovere, A Premolí, DP Soto, J Bannister. 2006. Pilgerodendron uviferum (D. Don) Florin. In Donoso $\mathrm{C}$ ed. Las especies arbóreas de los bosques templados de Chile y Argentina. Autoecología. Valdivia, Chile. Marisa Cúneo Ediciones. p. 82-91.

Núñez CI, MA Núñez, T Kitzberger. Sex-related spatial segregation and growth in a dioecious conifer along environmental gradients in northwestern Patagonia. Ecoscience 15(1): in press.

Martínez O. 1981. Flora y fitosociología de un relicto de Pilgerodendron uviferum (D. Don) Florin, en el Fundo San Pablo de Tregua (Valdivia-Chile). Bosque 4(1): 3-11.

Martínez O, AM Muñoz. 1988. Aspectos conservativos de las coníferas chilenas. Bosque 9(2): 77-82.

Moore DM. 1983. Flora of Tierra del Fuego. London, UK. Anthony Nelson. 396 p.

Myers N, RA Mittermeir, CG Mittermeir, GA Da Fonceca, J Kent. 2000. Biodiversity hotspots for conservation priorities. Nature 403: 853-858.

Oyarzún C, A Huber. 1999. Balance hídrico en plantaciones jóvenes de Eucalyptus globulus y Pinus radiata en el sur de Chile. Terra 17: 35-44.

Oyarzún C, L Nahuelhual, D Núñez. 2005. Los servicios ecosistémicos del bosque templado lluvioso: producción de agua y su valoración económica. Ambiente y Desarrollo 21(1): 88-95.

Pisano E. 1977. Fitogeografía de Fuego-Patagonia Chilena. Comunidades vegetales entre las latitudes $52^{\circ}$ y $56^{\circ} \mathrm{S}$. Anales Instituto de la Patagonia 8: 121-250.

Plaza JL. 2001. Dinámica de renovales de Ciprés de las Guaitecas (Pilgerodendron uviferum [D. Don] Florin) en la zona de Lago Vargas, Provincia de Capitán Prat, XI Región. Tesis Ingeniero Forestal. Valdivia, Chile. Facultad de Ciencias Forestales, Universidad Austral de Chile. 59 p.

Premoli AC, C Souto, T Allnutt, AC Newton. 2001. Effects of population disjunction on isozyme variation in the widespread Pilgerodendron uviferum. Heredity 87(3): 337-343.

Premoli AC, C Souto, A Rovere, TT Allnutt, AC Newton. 2002. Patterns of isozyme variation as indicators of biogeographic history in Pilgerodendron uviferum (D. Don) Florin. Diversity and Distributions 8: 57-66.

Rapoport EH, B Drausal. 1979. Tácticas y estrategias r, K y "SOS". In Rabinovich JE and G Halffter ed. Tópicos de Ecología Contemporánea. México DF, México. Fondo de Cultura Económica. p. 111-128.

Roig FA. 1991. Dendrocronología y dendroclimatología del bosque de Pilgerodendron uviferum en su área norte de dispersión. Boletín de la Sociedad Argentina de Botánica 27: 217-234. 
Roig FA, JA Boninsegna. 1991. Estudio sobre el crecimiento radial, basal, en altura y de las condiciones climáticas que afectan el desarrollo de Pilgerodendron uviferum. Revista Chilena de Historia Natural 64: 53-63.

Roig FA. 1992. Comparative wood anatomy of southern South American Cupressaceae. IAWA Bulletin 13: 151-162.

Rovere AE, AC Premoli, AC Newton. 2002. Estado de conservación del Ciprés de las Guaitecas (Pilgerodendron uviferum [D. Don] Florin) en la Argentina. Bosque 23(1): 11-19.

Smith-Ramírez C. 2004. The Chilean Coastal Range: a vanishing center of biodiversity and endemism in South American temperate rainforests. Biodiversity and Conservation 13: 373-393.

Soto DP. 2004. Estado de conservación de Pilgerodendron uviferum (D. Don) Florin, en la Cordillera de la Costa, Valdivia. Tesis Ingeniero Forestal. Valdivia, Chile. Facultad de Ciencias Forestales, Universidad Austral de Chile. 35 p.

Steel R, J Torrey. 1988. Bioestadística: principios y procedimientos. Bogotá, Colombia. McGraw-Hill. 622 p.

Szeicz J, A Lara, S Díaz, JC Aravena. 2000. Dendrochronological studies of Pilgerodendron uviferum in southwestern South America. In Roig FA ed. Dendrocronología en América Latina. Mendoza, Argentina. EDIUNC. p. 245-269.

Szeicz J, SG Haberle, KD Bennett. 2003. Dynamics of North Patagonian rainforest from fine-resolution pollen, charcoal and tree-ring analysis, Chonos Archipelago, Southern Chile. Austral Ecology 28: 413-422.
Veblen TT, RN Delmastro, JE Schlatter. 1976. The conservation of Fitzroya cupressoides and its environment in southern Chile. Environmental Conservation 3: 291-301.

Vertessy R. 1999. The impact of forestry on streamflows: a review. In Croke J, P Lane ed. Forest Management for the protection of water quality and quantity. Cooperative Research Centre for Hydrology, report 99/6. p. 93-109.

Villagrán C. 1988. Expansion of Magellanic Moorland during the late Pleistocene: Palynological evidence from northern Isla de Chiloé, Chile. Quaternary Research 30: 304-314.

Villagrán C. 1991. Historia de los bosques del sur de Chile durante el Tardiglacial y Postglacial. Revista Chilena de Historia Natural 64: 447-460.

Villagrán C, JJ Armesto. 2005. Fitogeografía histórica de la Cordillera de la Costa de Chile. In: Smith-Ramírez C, JJ Armesto and C Valdovinos ed. Historia, biodiversidad y ecología de los bosques costeros de Chile. Santiago, Chile. Universitaria. p. 99-115.

Walter KS, HJ Gillett. 1998. 1997 IUCN Red List of Threatened Plants. Gland, Switzerland and Cambridge, U.K. IUCN. $862 \mathrm{p}$.

Woda C. 2003. Standortfaktoren und Struktur eines temperierten Regenwaldes der chilenischen Küstenkordilliere. Schriften aus der Forstlichen Fakultät der Universität Göttingen. Frankfurt am Main, Germany. Sauerländer’s Verlag. 154 p. 